\title{
Erythrocyte Profile of Diploid and Triploid Silver Crucian Carp (Carassius auratus)
}

L. VETEŠNÍK, K. HALAČKA, V. LUSKOVÁ, S. LUSK

Institute of Vertebrate Biology AS CR, Brno, Czech Republic

Received August 16, 2005

Accepted March 16, 2006

\begin{abstract}
Vetešník L., K. Halačka, V. Lusková, S. Lusk: Erythrocyte Profile of Diploid and Triploid Silver Crucian Carp (Carassius auratus). Acta Vet. Brno 2006, 75: 203-207.

Haematological analysis was performed on 27 adult specimens of Carassius auratus irrespective of sex in 2003 and on 32 juveniles of distinguished sex in 2004. In this study we found that the ploidy level affected significantly $(p<0.01)$ the values of the erythrocyte count, mean corpuscular volume and mean corpuscular haemoglobin. Although we did not prove any significant effect of sex in juvenile diploids of $C$. auratus on the values of erythrocyte profile, the erythrocyte count, haematocrit value and haemoglobin content value were higher for males than for females. The erythrocyte count decreased significantly $(p<0.01)$ with increasing ploidy level. The index of haemoglobin content followed the same trend of a decreasing mean value with increasing ploidy level. Mean corpuscular volume and mean corpuscular haemoglobin increased with the increasing ploidy level $(p<0.01)$. Haematocrit value and mean corpuscular haemoglobin concentration did not significantly differ from the point of view of the ploidy level.
\end{abstract}

Carassius auratus, ploidy level, complete red blood count, erythrocyte nuclear dimensions

The alien species of silver crucian carp (Carassius auratus) has become an integral part of ichthyofauna of the Czech Republic in the last third of the $20^{\text {th }}$ century (Luskova et al. 2004). Original populations of $C$. auratus that have begun to occupy this region were considered to consist exclusively of triploid females with gynogenic reproduction (Peňáz et al. 1979). During the last decade, there have been increasingly frequent findings of males and specimens with various ploidy levels (diploid, triploid, tetraploid) in both sexes (Halačka et al. 2003; Lusková et al. 2004). Populations of this "species" gain the character of a diploid-polyploid complex with the majority of triploid individuals. In association with these changes, we studied a possible effect of ploidy level on the erythrocyte profile, as it has never been studied yet in native populations of Carassius auratus "gibelio". Most published studies which compared haematological indices to the ploidy level were performed in association with artificially induced changes of original natural ploidy level of given specimens (Beck and Biggers 1983; S vobodová et al. 1998; Flajšhans and Vajcová 2002, and others). Comparison of haematological indices of di- and triploid fish was most frequently performed in salmonids (B enfey and Sutterlin 1984ab; Benfey et al. 1984; Small and Benfey 1987; Cogswell et al. 2001 and others), sturgeons (Palíková et al. 1999; Flajšhans and Vajcová 2000), exceptionally in other fishes, as e.g. Ictalurus punctatus (Wolters et al. 1982), diploid and triploid hybrids of Ctenopharyngodon idella and Hypophthalmichthys nobilis (B eck and Biggers 1983), Tinca tinca (Flajšhans 1997; Svobodová et al. 1998), or Umbrina cirrosa (Ballarin et al. 2004). Different sizes of erythrocytes of diploids and triploids (Sezaki et al. 1977; Benfey et al. 1984; Flajšhans 1997; Svobodová et al. 1998) are frequently used for determination of ploidy level in some fish species, as e.g. Cobitis biwa (Sezaki et al. 1988), Cobitis taenia (B oron 1994) and Carassius auratus (Halačka and Lusková 2000).

Address for correspondence:

Ing. Lukáš Vetešník, Ph.D.

Institute of Vertebrate Biology AS CR

Květná 8, 60365 Brno, Czech Republic
Phone: +420543422533

Fax: +420543211346

E-mail: vetesnik@ivb.cz

http://www.vfu.cz/acta-vet/actavet.htm 


\section{Materials and Methods}

In the course of research on C. auratus from the area of confluence of Dyje and Morava rivers, we analyzed a total of 59 specimens. The first sampling was performed in August 2003 when we caught 27 adult specimens of $C$. auratus (5 diploids, 21 triploids and 1 tetraploid). Standard length (SL) and weight (W) were registered. Fish were released after blood sampling, and therefore sex was not determined. During the second sampling in October 2004, we caught 32 juvenile $C$. auratus (11 diploid males and 8 diploid females, and 13 triploid females). These fish were sacrificed after blood sampling, and their sex could be detected. Blood was sampled by a punction of the caudal vessel into a heparinized syringe. Analysis of the ploidy level was performed by the method of computer-assisted analysis of microscopic image (image cytometry, ICM, Plate VI, Fig. 1). Blood smears for ICM were stained $10 \mathrm{~min}$ in Harris haematoxylin (Sigma - Aldrich). Ploidy-diagnostic dimensions (area, perimeter, maximum and minimum diameter of erythrocyte nucleus) were determined by means of bright field microscopy, image capture by CCD camera and processing the image information by Olympus MicroImage 4.0 software (Flajšhans 1996; Flajšhans 1997; Halačka and Lusková 2000). The following indices of erythrocyte profile were registered for statistic evaluation: erythrocyte count (Er), haematocrit value $(\mathrm{PCV})$, haemoglobin content $(\mathrm{Hb})$ and derived indices: mean corpuscular volume $(\mathrm{MCV}=\mathrm{PCV} / \mathrm{Er})$, mean corpuscular haemoglobin $(\mathrm{MCH}=\mathrm{Hb} / \mathrm{Er})$ and mean corpuscular haemoglobin concentration $(\mathrm{MCHC}=$ Hb/PCV). Methodology followed S vobodová et al. (1986) and Lusková (1996). The effect of the ploidy level on the haematological indices was tested using Mann - Whitney test in the Statistica 6.0 software.

\section{Results}

Values of standard length, weight and of haematological indices of 27 adult specimens of C. auratus captured in 2003 without sex differentiation are given in Table 1 . The erythrocyte count decreased significantly with the increasing ploidy level: $1.69 \pm 0.19 \mathrm{~T}^{-1} \mathrm{l}^{-1}$ in diploid specimens, $1.06 \pm 0.12 \mathrm{~T} . \mathrm{l}^{-1}$ in triploids and $0.59 \mathrm{~T}^{\mathrm{T}} \mathrm{l}^{-1}$ in a tetraploid specimen. The index of haemoglobin content followed the same trend of a decreasing mean value with the increasing ploidy level: $79.00 \pm 5.79 \mathrm{~g} . \mathrm{l}^{-1}$ in diploid specimens, $74.38 \pm 11.58 \mathrm{~g} . \mathrm{l}^{-1}$ in triploid specimens, and $59.00 \mathrm{~g} . \mathrm{l}^{-1}$ in the tetraploid specimen (Table 1). Mean values of the mean corpuscular volume $(223.50 \pm 21.75 \mathrm{fl}$ in diploids, $319.47 \pm 72.34 \mathrm{fl}$ in triploids and 508.47 $\mathrm{fl}$ in a tetraploid specimen) and mean corpuscular haemoglobin $(46.99 \pm 3.89 \mathrm{pg}$ in diploids, $71.18 \pm 12.53 \mathrm{pg}$ in triploids and $100.00 \mathrm{pg}$ in a tetraploid specimen) indices increased with the increasing ploidy level in accordance with their mathematic interpretation. Haematocrit value and mean corpuscular haemoglobin concentration did not significantly differ from the point of view of the ploidy level (Table 1).

Table 1. Comparison of values of erythrocyte profile in C. auratus specimens differing with ploidy level $(2 \mathrm{n}, 3 \mathrm{n}, 4 \mathrm{n})$ in $2003(* * p<0.01)$.

\begin{tabular}{|l|c|c|c|c|c|c|}
\hline \multirow{2}{*}{ Indices } & \multirow{2}{*}{ Unit } & \multicolumn{2}{|c|}{ 2n } & \multicolumn{2}{|c|}{$3 \mathrm{n}$} & n \\
\cline { 3 - 7 } & & mean & SD & mean & SD & mean \\
\hline Number of individuals (n) & & 5 & & 21 & & 1 \\
Standard length (SL) & $\mathrm{mm}$ & 233 & 39.17 & 261 & 22.53 & 230 \\
Body weight (W) & $\mathrm{g}$ & 406 & 212.56 & 601 & 158.35 & 418 \\
Erythrocyte count (Er) & $\mathrm{T} \cdot \mathrm{l}^{-1}$ & $1.69^{* *}$ & 0.19 & $1.06^{* *}$ & 0.12 & 0.59 \\
Haematocrit value (PCV) & $1 \cdot \mathrm{l}^{-1}$ & 0.38 & 0.05 & 0.33 & 0.06 & 0.30 \\
Haemoglobin content (Hb) & $\mathrm{g} \cdot \mathrm{l}^{-1}$ & 79.00 & 5.79 & 74.38 & 11.58 & 59.00 \\
Mean corpuscular volume (MCV) & $\mathrm{fl}$ & $223.50^{* *}$ & 21.75 & $319.47^{* *}$ & 72.34 & 508.47 \\
Mean corpuscular haemoglobin (MCH) & $\mathrm{pg}$ & $46.99^{* *}$ & 3.89 & $71.18^{* *}$ & 12.53 & 100.00 \\
Mean corp. hem. concentration (MCHC) & $1 \cdot \mathrm{l}^{-1}$ & 0.21 & 0.03 & 0.23 & 0.03 & 0.20 \\
Nuclear area & $\mu \mathrm{m}^{2}$ & $10.89^{* *}$ & 0.45 & $14.83^{* *}$ & 0.41 & 17.76 \\
Nuclear perimeter & $\mu \mathrm{m}$ & $12.39^{* *}$ & 0.34 & $15.12^{* *}$ & 0.28 & 16.93 \\
Nuclear major axis & $\mu \mathrm{m}$ & $4.69^{* *}$ & 0.19 & $5.97^{* *}$ & 0.15 & 6.73 \\
Nuclear minor axis & $\mu \mathrm{m}$ & $2.66^{* *}$ & 0.03 & $2.85^{* *}$ & 0.04 & 3.00 \\
\hline
\end{tabular}

Values of standard length, weight and of haematological indices of 32 juveniles of C. auratus captured in 2004 with distinguished sex are given in Table 2. As no effect of sex 
was found on the values of haematological parameters, the category of juvenile diploids was pooled and assessed regardless of sex. The category of triploids was female monosex. The erythrocyte count decreased significantly with the increasing ploidy level (see Table 2). The index of the haemoglobin content followed the same trend of a decreasing mean value with the increasing ploidy level. Mean values of the mean corpuscular volume and mean corpuscular haemoglobin indices increased with the increasing ploidy level. Haematocrit value and mean corpuscular haemoglobin concentration did not significantly differ from the point of view of the ploidy level (Table 2$)$.

The ploidy level affected significantly $(p<0.01)$ the values of Er, MCV and MCH (Tables $1,2)$. A highly significant increment in values of erythrocyte nuclear area, nuclear perimeter, nuclear major axis and nuclear minor axis in triploid specimens compared to diploid ones (Tables 1,2) were also reflected in the MCH and MCV indices.

Table 2. Comparison of values of erythrocyte profile in C. auratus specimens differing with ploidy level $(2 \mathrm{n}, 3 \mathrm{n})$ in $2004(* p<0.05 ; * * p<0.01)$.

\begin{tabular}{|l|c|c|c|c|c|}
\hline \multirow{2}{*}{ Indices } & \multirow{2}{*}{ Unit } & \multicolumn{2}{|c|}{ 2n males + females } & \multicolumn{2}{|c|}{ 3n females } \\
\cline { 3 - 6 } & & mean & SD & mean & SD \\
\hline Number of individuals (n) & & 19 & & 13 & \\
Standard length (SL) & $\mathrm{mm}$ & 89 & 4.45 & 91 & 3.95 \\
Body weight (W) & $\mathrm{g}$ & 22 & 3.16 & 24 & 2.90 \\
Erythrocyte count (Er) & $\mathrm{T} \cdot \mathrm{l}^{-1}$ & $1.70^{* *}$ & 0.12 & $1.05^{* *}$ & 0.10 \\
Haematocrit value (PCV) & $1 \cdot \mathrm{l}^{-1}$ & 0.31 & 0.04 & 0.31 & 0.03 \\
Haemoglobin content (Hb) & $\mathrm{g} \cdot \mathrm{l}^{-1}$ & $68.95^{*}$ & 5.64 & $65.43^{*}$ & 9.04 \\
Mean corpuscular volume (MCV) & $\mathrm{fl}$ & $185.09^{* *}$ & 20.85 & $297.84^{* *}$ & 40.52 \\
Mean corpuscular haemoglobin (MCH) & $\mathrm{pg}$ & $40.51^{* *}$ & 2.69 & $62.27^{* *}$ & 6.94 \\
Mean cor. hem. concentration (MCHC) & $1 \cdot \mathrm{l}^{-1}$ & 0.21 & 0.03 & 0.21 & 0.03 \\
Nuclear area & $\mu \mathrm{m}^{2}$ & $11.01^{* *}$ & 0.48 & $15.52^{* *}$ & 0.35 \\
Nuclear perimeter & $\mu \mathrm{m}$ & $12.65^{* *}$ & 0.44 & $15.67^{* *}$ & 0.22 \\
Nuclear major axis & $\mu \mathrm{m}$ & $4.89^{* *}$ & 0.23 & $6.29^{* *}$ & 0.12 \\
Nuclear minor axis & $\mu \mathrm{m}$ & $2.64^{* *}$ & 0.05 & $2.83^{* *}$ & 0.04 \\
\hline
\end{tabular}

\section{Discussion}

There are no current erythrocyte profile values in C. auratus from Central European wildlife. Only Sezaki et al. (1991) compared the effect of ploidy level on erythrocyte profile of diploid and triploid specimens of $C$. auratus langsdorfii. Considering the range of weight ( $7-25 \mathrm{~g})$ stated by these authors, their specimens were probably juvenile. Value of Er significantly decreased with the increasing ploidy level $\left(1.97 \pm 0.18\right.$ T. $\mathrm{l}^{-1}$ in diploids and $1.44 \pm 0.09 \mathrm{~T}^{-\mathrm{l}^{-1}}$ in triploids). Haemoglobin content followed the same trend of decreasing mean value with increasing ploidy level $\left(96.00 \pm 7.00 \mathrm{~g} . \mathrm{l}^{-1}\right.$ in diploids, $91.00 \pm 9.00 \mathrm{~g}^{-1} \mathrm{l}^{-1}$ in triploids). Haematocrit value $\left(0.42 \pm 0.031 .1^{-1}\right)$ and the derived MCHC value $\left(0.23 \pm 0.011 .1^{-1}\right)$ did not differ significantly with ploidy levels. Mean values of MCV and $\mathrm{MCH}$ did not increase significantly with the increasing ploidy level (Sezaki et al. 1991). All values registered in this subspecies showed a similar trend, but absolute values were higher than ours.

Although we did not prove any significant effect of sex in juvenile diploids of $C$. auratus on the values of erythrocyte profile, Er, PCV and $\mathrm{Hb}$ values were higher for males than for females. Most studies give either significantly, or non-significantly higher values of Er, PCV and $\mathrm{Hb}$ for males than for females. Hlavová (1993) came to this conclusion in Thymallus thymallus, Lusková et al. (1995) in Chondrostoma nasus, Lusková and Halačka (1996) in Barbus barbus and S vobodová et al. (1998) in Tinca tinca. 
According to Ihssen et al. (1990) and Benfey (1999), in polyploid specimens the volume of the entire cell increases with the increasing volume of cell nucleus, which is associated with reduction of the number of cells in the particular tissue.

Although we did not measure the oxygen content in the blood of diploids and triploids, our values of erythrocyte profile indices support hypotheses of the authors mentioned below, on higher oxygenation capacity of blood complex of diploid fish compared to triploids, in association with decreased $\mathrm{Er}$ and $\mathrm{Hb}$ with increased ploidy level of C. auratus. Svobodová et al. (1998) mentioned a possibility of lower oxygenation capacity of blood in triploid Tinca tinca. Enhanced respiration frequency in triploid C. auratus langsdorfii, compared to diploids, was reported by Sezaki et al. (1991). According to Graham et al. (1985) in Salmo salar the oxygen content in the blood of triploids gained only $68 \%$ of those in diploids. According to Benfey and Sutterlin (1984b), there was no difference between diploid and triploid Salmo salar in the oxygen consumption as the fish probably compensated it by enhanced respiration frequency (Sezaki et al. 1991).

According to conclusions of Benfey (1999), the majority of haematological studies of polyploid fish mention similar haematocrit value of specimens with different ploidy levels, in accordance with our results.

\section{Červený krevní obraz u diploidního a triploidního karasa stříbřitého (Carassius auratus)}

Hematologické vyšetření jsme provedli v roce 2003 u 27 adultních jedinců Carassius auratus bez diferenciace pohlaví a v roce 2004 u 32 juvenilních jedinců pohlavně diferencovaných. V této studii ploidie významně ovlivnila $(p<0,01)$ hodnoty ukazatelů počtu erytrocytů, středního objemu erytrocytů a hemoglobin erytrocytu. I když jsme u juvenilních diploidů $C$. auratus statisticky významně neprokázali vliv pohlaví na hodnoty červeného krevního obrazu, počet erytrocytů, hematokritovou hodnotu a koncentraci hemoglobinu měli samci vyšší než samice. Počet erytrocytů se statisticky významně snižoval $(p<0,01)$ se zvyšováním ploidie. Shodný klesající trend průměrných hodnot s růstem úrovně ploidie měl ukazatel koncentrace hemoglobinu. Střední objem erytrocytů a hemoglobin erytrocytu se s růstem ploidie zvyšovaly $(p<0,01)$. Hematokritová hodnota i hodnota střední barevné koncentrace se z hlediska ploidie statisticky významně nelišily.

\section{Acknowledgements}

This study was supported financially by the project No. 206/05/2159 from the Grant Agency of the Czech Republic.

\section{References}

BALLARIN L, DALL'ORO M, BERTOTTO D, LIBERTINI A, FRANCESCON A, BARBARO A 2004 : Haematological parameters in Umbrina cirrosa (Teleostei, Sciaenidae): a comparison between diploid and triploid specimens. Comp Biochem Physiol A 138: 45-51

BECK ML, BIGGERS CJ 1983: Erythrocyte measurements of diploid and triploid Ctenopharyngodon idella x Hypopthalmichthys nobilis hybrids. J Fish Biol 22: 497-502

BENFEY TJ 1999: The physiology and behavior of triploid fishes. Res Fish Sci 7: 39-67

BENFEY TJ, SUTTERLIN AM 1984a: The haematology of triploid landlocked Atlantic salmon (Salmo salar L.). J Fish Biol 24: 333-338

BENFEY TJ, SUTTERLIN AM 1984b: Oxygen utilization by triploid landlocked Atlantic salmon (Salmo salar L.). Aquaculture 42: 69-73

BENFEY TJ, SUTTERLIN AM, THOMPSON RJ 1984: Use of erythrocyte measurements to identify triploid salmonids. Can J Fish Aquat Sci 41: 980-984

BORON A 1994: Use of erythrocyte measurements to detect natural triploids of spined loach Cobitis taenia (L.). Cytobios 78: 197-202

COGSWELL AT, BENFEY TJ, SUTTERLIN AM 2001: The hematology of diploid and triploid transgenic Atlantic salmon (Salmo salar). Fish Physiol Biochem 24: 271-277 
FLAJŠHANS M 1996: Ploidy level determination in tench (Tinca tinca L., Pisces: Cyprinidae) by computer assisted image analysis of erythrocyte nuclei. In: DIPS `96, Sb. semináře Digital Image Processing (Kapoun K. Ed.), Univ. South Bohem., Ceské Budějovice, pp. 55-56.

FLAJŠHANS M 1997: A model approach to distinguish diploid and triploid fish by means of computer-assisted image analysis. Acta vet Brno 66: 101-110

FLAJSSHANS M, VAJCOVÁ V 2000: Odd ploidy levels in sturgeons suggest a backcross of interspecific hexaploid sturgeon hybrids to evolutionarily tetraploid and/or octaploid parental species. Folia Zool 49: 133-138

GRAHAM MS, FLETCHER GL, BENFEY TJ 1985: Effect of triploidy on blood oxygen content of Atlantic salmon. Aquaculture 50: 133-139

HALAČKA K, LUSKOVÁ V 2000: Polyploidie u karasa stříbřitého (Carassius auratus) v dolním toku Dyje determinace pomocí velikostí jader erytrocytů. In: Mikešová, J. (Ed.) Sb. referátů IV. České ichthyologické konference, pp. 110-113 (in Czech).

HALAČKA K, LUSKOVÁ V, LUSK S 2003: Carassius „gibelio“ in fish communities of the Czech Republic. Ecohydrol Hydrobiol 3: 133-138

HLAVOVÁ V 1993: Reference values of the haematological indices in grayling (Thymallus thymallus Linnaeus). Comp Biochem Physiol 105A: 525-532

IHSSEN PE, MCKAY LR, MCMILLAN I, PHILLIPS RB 1990: Ploidy manipulation and gynogenesis in fishes: Cytogenetic and fisheries application. Trans Am Fish Soc 119: 698-717

LUSKOVÁ V 1996: Annual cycles and normal values of hematological parameteres in fishes. Acta Sc Nat Brno 31: $1-70$

LUSKOVÁ V, HALAČKA K 1996: Some hematological indices in barbel, Barbus barbus. Folia Zool 45 (SUPPL. 1): 103-108

LUSKOVÁ V, HALAČKA K, LUSK S 1995: Dynamics of the haemogram in the nase, Chondrostoma nasus. Folia Zool 44 (SUPPL. 1): 69- 74

LUSKOVÁ V, HALAČKA K, VETEŠNÍK L, LUSK S 2004: Changes of ploidy and sexuality status of "Carassius auratus" populations in the drainage area of the River Dyje (Czech Republic). Ecohydrol Hydrobiol 4: 165-171

PALÍKOVÁ M, MAREŠ J, JIRÁSEK J 1999: Characteristics of leukocytes and thrombocytes of selected sturgeon species form intensive breeding. Acta vet Brno 68: 259-264

PENÁZ M, RÁB P, PROKEŠ M 1979: Cytological analysis, gynogenesis and early development of Carassius auratus gibelio. Acta Sc Nat Brno 13: 33 p.

SEZAKI K, KOBAYASI H, NAKAMURA M 1977: Size of erythrocytes in the diploid and triploid specimens of Carassius auratus langsdorfi. Jap J Ichtyol 24: 135-140

SEZAKI K, WATABE S, HASHIMOTO K 1988: Haematological parameters and erythrocyte enzyme activities associated with increase in ploidy status of the spinous loach, Cobitis biwae Jordan and Snyder. J Fish Biol 32 : $149-150$

SEZAKI K, WATABE S, TSUKAMOTA K, HASHIMOTO K 1991: Effects of increase in ploidy status on respiratory function of ginbuna Carassius auratus langsdorfi (Cyprinidae). Comp Biochem Physiol 99A: 123-127

SMALL SA, BENFEY TJ 1987: Cell size in triploid salmon. J. Exp. Zool. 241: 339-342

SVOBODOVÁ Z, KOLÁŘOVÁ J, FLAJŠHANS M 1998: The first findings of the differences in complete blood count between diploid and triploid tench, Tinca tinca L. Acta vet Brno 67: 243-248

SVOBODOVÁ Z, PRAVDA D, PALÁČKOVÁ J 1991: Unified methods of haematological examination of fish. Research Institute of Fish Culture and Hydrobiology, Vodňany, Czech Republic, 31 p.

WOLTERS WR, CHRISMAN CL, LIBEY GS 1982: Erythrocyte nuclear measurements of diploid and triploid channel catfish, Ictalurus punctatus (Rafinesque). J Fish Biol 20: 253-258 
Plate VI

Vetešník L. et al.: Erythrocyte profile ... pp. 203-207

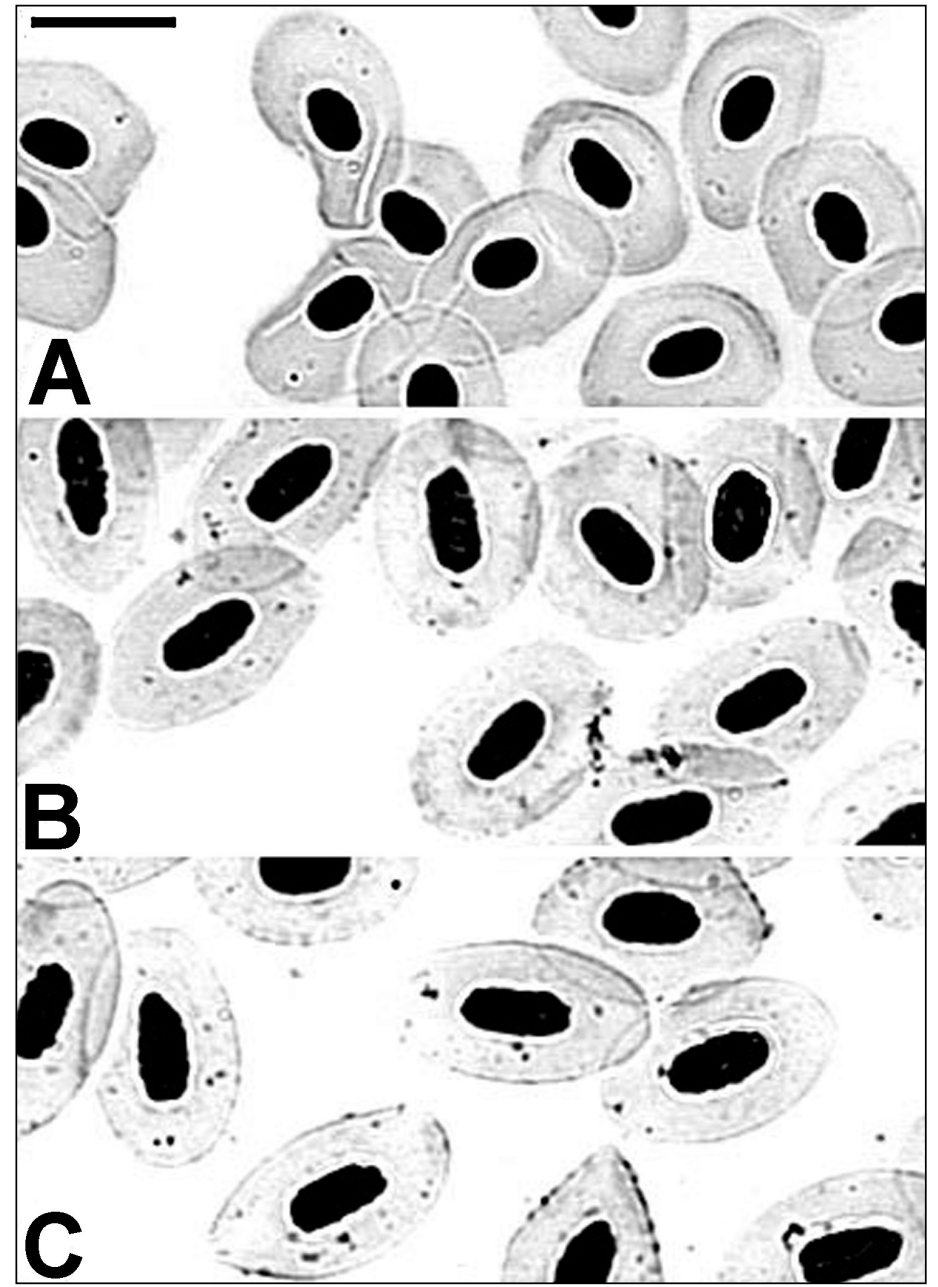

Size comparison of erythrocyte nuclei of $C$. auratus according to the ploidy level (A - diploid, B - triploid, C - tetraploid). Bar indicates $10 \mu \mathrm{m}$ 